\title{
The Diagnosis of Industrial Lead Poisoning
}

\author{
SHEILA L. M. GIBSON, J. C. MACKENZIE, and A. GOLDBERG \\ From the University Department of Medicine, Gardiner Institute, Western Infirmary, Glasgow, W.I
}

A series of 100 lead workers from different industries, 9I at work and nine admitted to hospital with lead poisoning, was studied in order to define more clearly the clinical and biochemical criteria of lead poisoning in three stages-(A) a presymptomatic state of lead exposure (37 men), (B) a state of mild symptoms or mild anaemia (45 men), and (C) frank lead poisoning with severe symptoms and signs (I 8 men).

The tests used were haemoglobin, reticulocyte count, and blood lead, and urinary lead, coproporphyrin, $\delta$-aminolaevulinic acid (ALA), and porphobilinogen (PBG) estimations. Of these, the urinary lead was similar for all three groups and the blood lead estimation was of less value for determining the clinical group of the men than the haemoglobin and urinary coproporphyrin or ALA estimations, which correlated well with the clinical assessment and with each other but showed no correlation with the urinary and blood lead levels. PBG levels became raised only with the onset of symptoms of lead poisoning.

A haemoglobin of $13 \mathrm{~g} . / 100 \mathrm{ml}$. (90\%) or less is a cautionary sign. Urinary coproporphyrin above $80 \mu \mathrm{g}$. roo mg. creatinine $(800 \mu \mathrm{g}$./litre), ALA above $2.0 \mathrm{mg}$. $/ 100 \mathrm{mg}$. creatinine $(2.0 \mathrm{mg} . \%)$, and PBG above $0.15 \mathrm{mg} . / 100 \mathrm{mg}$. creatinine $(0.15 \mathrm{mg} . \%)$ were almost always associated with symptoms or signs and were therefore considered to be the upper safety limits. Although the blood lead level does not differentiate between lead toxicity and lead exposure, values above $60 \mu \mathrm{g}$. lead/100 g. blood should alert the physician to carry out other tests.

In addition to the above tests, blood pressure, blood urea, and serum uric acid estimations were performed on all the men in order to elucidate the possible role of lead in the production of renal damage. Blood pressure and serum uric acid levels were similar for all three groups but the blood urea level was raised in group C. The reason for this finding was not established.

It was found that scrap metal burning, battery manufacturing, and ship-breaking constituted the gravest lead hazards encountered in this survey whereas wire manufacture constituted the least. Workers in the most modern factory, a car-body pressing plant, gave average values just below the danger levels for the urinary coproporphyrin and ALA estimations despite apparently efficient protective measures. This finding underlines the importance of the medical supervision of lead workers.

Lead and its compounds have been used by man for at least six thousand years (Brunton, 1937) and today the demands of industry for lead rise steadily. Its toxic properties were first recognized by Hippocrates (Hunter, 1962) and over the centuries more has been written about the causation and symptomatology of poisoning by lead than by any other toxic agent (Johnstone, I966).

The manifestations of overt lead poisoning are well documented, but the clinical relevance of the many tests used for its diagnosis have not yet been clearly defined. Much has been achieved in the disposal of, and protection from, lead dust and fume, the main hazards in the lead industry, and the routine screening of all statutory workers for

Received for publication September 15, 1967 signs of developing lead toxicity is now required by law (Ministry of Labour, 1965). There are, however, no agreed criteria as to when a state of lead exposure merges into a dangerous clinical state of lead toxicity. Haemoglobin and basophilic stippled cell counts, urinary lead, coproporphyrin, and $\delta$-aminolaevulinic acid (ALA) levels, and blood lead levels have all been correlated with lead exposure. The present study has accordingly been undertaken to determine the laboratory tests likely to be most useful in the early diagnosis of lead intoxication. An attempt has also been made to define the clinical and biochemical criteria of lead intoxication in three stages-(A) a presymptomatic state of lead exposure in which the men display neither symptoms nor signs, (B) a stage of mild symptoms, e.g., occasional abdominal pain or mild 
anaemia (I2 to $13 \mathrm{~g} . / 100 \mathrm{ml}$.), and (C) severe symptoms and signs requiring hospital treatment.

\section{Clinical Material}

The survey included roo subjects from several industries: nine patients admitted to hospital with acute lead poisoning from the ship breaking, scrap metal, and electric accumulator industries and 9I men studied at work from the car-body manufacturing, ship-breaking, electric accumulator, wiremaking, lead refining, and scrap metal industries. At the factory a brief history was taken and a clinical examination was performed; blood and random urine samples were collected, taking every possible precaution to avoid contamination of the samples. Any man with a history of peptic ulcer was excluded from the series. If deleading therapy was planned all investigations were completed before this was started.

The roo men were classified into the above three groups: A, 37 men with neither symptoms nor signs; B, 45 men with either mild symptoms or mild anaemia (I2 to $13 \mathrm{~g}$./100 $\mathrm{ml}$.); and C, 18 men with severe symptoms and signs. The latter group contained the nine hospital patients and nine men initially studied at work, of whom six were subsequently admitted to hospital.

\section{Laboratory Methods}

A haemoglobin and reticulocyte count, blood lead (Gonzales, Vance, and Helpern, 1954, modified by Goldberg, Smith, and Lochhead, 1963), blood urea (Skeggs, 1957) and serum uric acid (Caraway, 1955), and urine lead (Gonzales et al., I954), coproporphyrin (Rimington, 196I), ALA (Mauzerall and Granick, 1956), and creatinine (Hawk, Oser, and Summerson, 1953, adapted for the AutoAnalyzer) were performed on all men. The urinary lead, coproporphyrin, and ALA values were expressed relative to $100 \mathrm{mg}$. creatinine to eliminate as far as possible variations in concentration of the random samples. In a series of 24 -hour urine collections performed on 20 normal adults, it was found that the scatter in values for lead, coproporphyrin, and ALA was least when expressed relative to $100 \mathrm{mg}$. urinary creatinine (Fig. I). An estimation of urinary porphobilinogen (PBG) was performed on some of the men by the method of Mauzerall and Granick (1956) and was also expressed relative to $100 \mathrm{mg}$. creatinine.

\section{Results}

Haemoglobin and Reticulocyte Count Fiftyfour men in this series (i.e., $54 \%$ ) had a haemoglobin level less than $13 \mathrm{~g}$./100 $\mathrm{ml}$. and $3 \mathrm{I}$ of these had a reticulocyte count greater than $2 \%$. Only three of the 46 men with a haemoglobin greater than 13 g. $/ 100 \mathrm{ml}$. had a reticulocyte count greater than $2 \%$.

All 37 men in group A had haemoglobins greater than $13 \mathrm{~g}$./100 ml. by definition of this group. Two of these, however, had a raised reticulocyte count. Of the 45 men in group B, 36 had haemoglobins of $13 \mathrm{~g} . / 100 \mathrm{ml}$. or less while 19 had a raised reticulocyte count. Of the 18 men in group $C$, all had haemoglobins of $13 \mathrm{~g}$./ $100 \mathrm{ml}$. or less and 13 had a raised reticulocyte count.

Urinary Lead The normal range for urinary lead, calculated on the 20 normal adults, was $0-18.09 \mu \mathrm{g}$. lead/100 mg. creatinine, with a mean of $3.89 \mu \mathrm{g} . / 100 \mathrm{mg}$. creatinine. The means for this estimation were $22.4 \mathrm{I}, 27.49$, and $27.68 \mu \mathrm{g}$. lead/ $100 \mathrm{mg}$. creatinine for groups $\mathrm{A}, \mathrm{B}$, and $\mathrm{C}$ respectively (Table I). None of these differed significantly $(P>0.3)$ from the other although all were signi-

TABLE I

Mean Values and Standard Deviations of Urinary Lead, Urinary Coproporphyrin, Urinary ALA, AND BLOOD LEAD FOR THE THREE GROUPS

\begin{tabular}{|c|c|c|c|c|}
\hline \multirow[b]{2}{*}{ Group } & \multicolumn{3}{|c|}{ Urine } & \multirow[b]{2}{*}{$\begin{array}{l}\text { Blood Lead } \\
(\mu \mathrm{g} . / \mathrm{r} \infty \mathrm{g} .)\end{array}$} \\
\hline & $\begin{array}{c}\text { Lead } \\
(\mu g . / 100 \text { mg. creatinine })\end{array}$ & $\begin{array}{c}\text { Coproporphyrin } \\
(\mu g . / 100 \text { mg. creatinine })\end{array}$ & $\begin{array}{c}A L A \\
\text { (mg./100 mg. creatinine) }\end{array}$ & \\
\hline A & $22 \cdot 4 I(I 6 \cdot 2 I)$ & $54.56(38 \cdot 68)$ & $I \cdot 48(1 \cdot 24)$ & $5 \mathrm{I} \cdot 72(33 \cdot 8 \mathrm{I})$ \\
\hline B & $27 \cdot 49(21 \cdot 87)$ & I $10.07(67.4 I)$ & $2 \cdot 62(1 \cdot 46)$ & $73 \cdot 69(44 \cdot 21)$ \\
\hline C & $27.68(16.58)$ & $143.55(72 \cdot 41)$ & $4.29(1 \cdot 95)$ & $83.94(44 \cdot 14)$ \\
\hline
\end{tabular}

Standard deviations are shown in parentheses. 
URINE LEAD

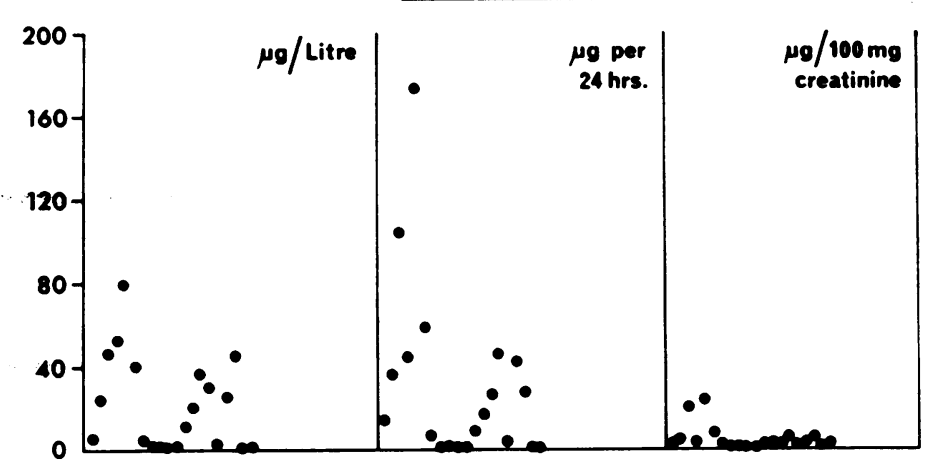

URINE COPROPORPHYRIN

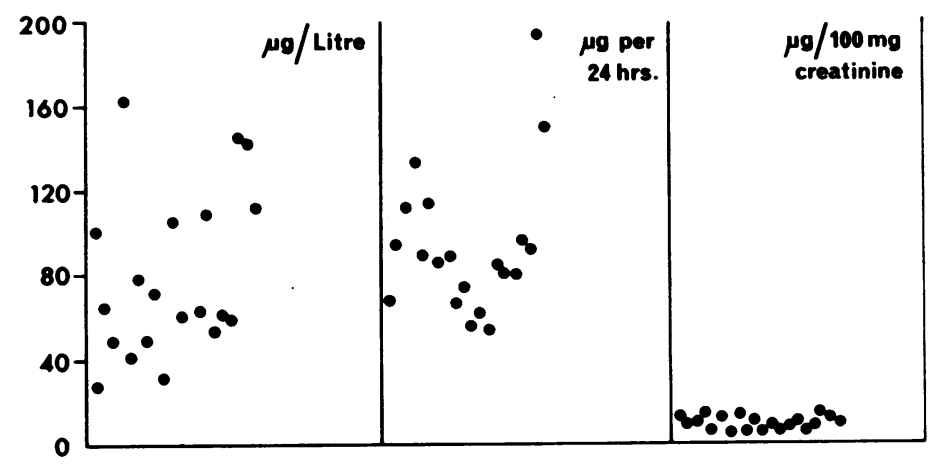

URINE ALA

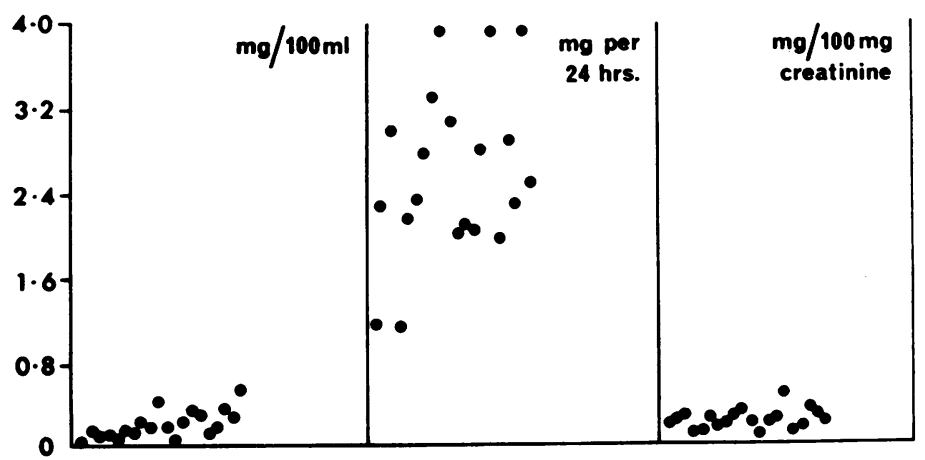

FIG. I. Comparison of the values for urinary lead, coproporphyrin, and $\delta$-aminolaevulinic acid (ALA) in 20 normal adults.

ficantly higher than the normal mean. Urinary lead did not correlate with any other estimation $(r=$ $0 \cdot 17$ ).

Urinary Coproporphyrin The normal range for urinary coproporphyrin was 2.04-15.64 $\mu \mathrm{g}$./
100 mg. creatinine, with a mean value of $8.84 \mu \mathrm{g}$./ $100 \mathrm{mg}$. creatinine. Five subjects in group $\mathrm{A}$ and four in group B were within the nomal range or just above the upper limit of normal (Fig. 2). No subject in group $\mathrm{C}$ was normal.

The means for this estimation were $54.56,110.07$, 
A B C

URINE LEAD

$\mu \mathrm{g} / 100 \mathrm{mg}$ Creatinine

160

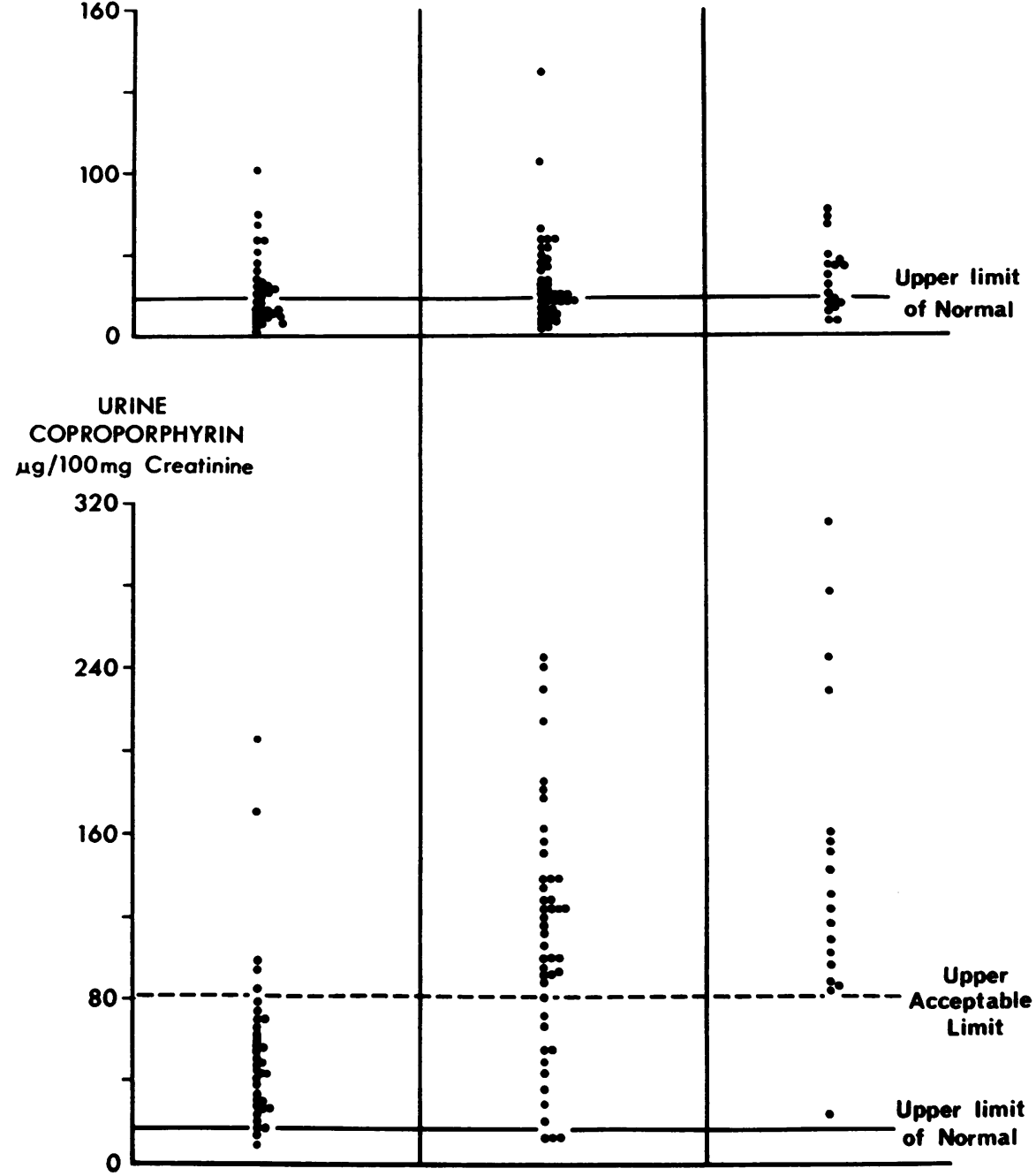

FIG. 2a. Comparison of the values for urinary lead and urinary coproporphyrin for the three groups $A, B$, and $C$.

and $143.55 \mu \mathrm{g}$. coproporphyrin/100 mg. creatinine for groups $A, B$, and $C$ respectively (Table I), all of which differ significantly from each other $(P<$ $0.05)$. All, moreover, are greatly in excess of the normal mean.

Although the scatter is large (Fig. 2), giving considerable overlap in three groups, the results indicate that the occurrence of a coproporphyrin level of $80 \mu \mathrm{g}$./100 mg. creatinine or over is compatible with the presence of symptoms. Values above this level include all but one man (94\%) of group C, $75 \%$ of group B, and only $14 \%$ of group A. A similar separation occurs when the urinary coproporphyrin results are expressed in $\mu \mathrm{g}$./litre, when a coproporphyrin level of $800 \mu \mathrm{g}$./litre or over is compatible with the presence of symptoms indicative of toxicity.

Urinary $\delta$-Aminolaevulinic Acid The normal range for this estimation was found to be 0.04- 
A B C

URINE ALA

$\mathrm{mg} / 100 \mathrm{mg}$ Creatinine

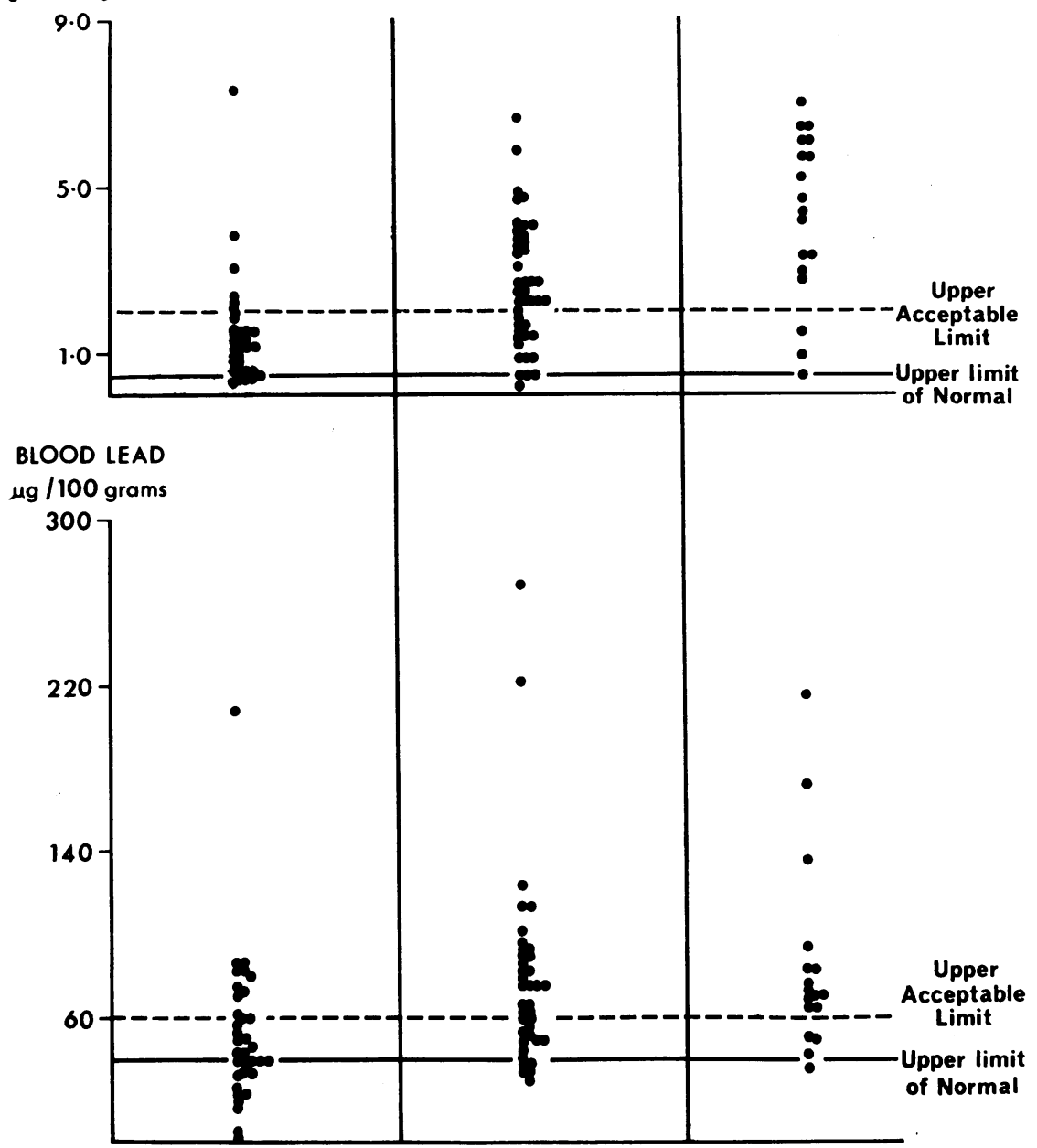

FIG. 2b. Comparison of the values for urinary ALA and blood lead for the three groups A, B, and C.

$0.44 \mathrm{mg}$. ALA/100 mg. creatinine with a mean value of $0.24 \mathrm{mg}$. $/ \mathrm{roO} \mathrm{mg}$. creatinine. Three subjects from group A, two from group B, and one from group $\mathrm{C}$ are within the normal range (Fig. 2). The three subjects in group A correspond to three of the five in group A with normal coproporphyrin levels, while the two in group B correspond to two of the four with normal coproporphyrin levels in that group. The one man in group $C$ with urinary ALA within the normal range had a high urinary coproporphyrin (122.54 $\mu \mathrm{g}$./100 mg. creatinine). The mean urinary excretions of ALA for groups
$A, B$, and C respectively are $I \cdot 48,2 \cdot 62$, and $4 \cdot 29 \mathrm{mg}$. / IOO mg. creatinine (Table I). These are all considerably higher than the normal mean and differ significantly from each other $(P<0.05)$. Again, however, considerable overlap is evident (Fig. 2) but any urinary ALA value of $2 \mathrm{mg}$. $/ 100 \mathrm{mg}$. creatinine or over is compatible with symptoms of lead poisoning indicative of toxicity. This corresponds to the value of $80 \mu \mathrm{g}$. coproporphyrin/ IOO mg. creatinine (Figs 2 and 4). A high degree of correlation was found between urinary coproporphyrin and urinary ALA (Fig. 4) $(r=0.79)$. 
Urinary Porphobilinogen This estimation was performed on the men with acute lead intoxication admitted to hospital during the course of this study and in all cases was found to be slightly raised. On the other hand, random PBG estimations performed on some of the men studied at work had all been found to be normal. In view of this fact, in all subsequent cases an estimation was made of the urinary PBG, which was determined in 62 of the total of roo men studied, I6 of group A, 30 of group $\mathrm{B}$, and $\mathrm{I} 6$ of group $\mathrm{C}$.

The normal range is $0.02-0.14 \mathrm{mg} . / 100 \mathrm{mg}$. creatinine and the normal mean $0.08 \mathrm{mg}$. $/ 100 \mathrm{mg}$. creatinine. The means were $0.08,0.12$, and 0.34 $\mathrm{mg}$ // $100 \mathrm{mg}$. creatinine for groups $\mathrm{A}, \mathrm{B}$, and $\mathrm{C}$ respectively. While the mean of $B$ is just significantly higher than that of $A(P=0.05)$, the mean of $C$ is significantly higher than those of either $A$ or $B(P<0.01)$. No individuals in group $A$, eight in group $B$, and all but two in group $C$ had a raised PBG (Fig. 3). All patients admitted to hospital with acute lead intoxication had PBG values above the normal range.
Blood Lead The upper limit of normal for this estimation is $40 \mu \mathrm{g} . / 100 \mathrm{~g}$. blood, in this department, with a range of II $40-49 \cdot 10 \mu \mathrm{g}$. $/ 100 \mathrm{~g}$. (Goldberg et al., 1963). This is lower than the figure of $60 \mu \mathrm{g} . / 100 \mathrm{~g}$. blood given by Kehoe, Thamann, and Cholack (1935) or that of Byers (1959) of 60-80 $\mu \mathrm{g}$./I00 g. blood.

The mean levels for groups $\mathrm{A}, \mathrm{B}$, and $\mathrm{C}$ respectively were $5 \mathrm{I} \cdot 72,73 \cdot 69$, and $83.94 \mu \mathrm{g}$. lead/ roo g. blood (Table I). Fifteen men $(41 \%)$ in group $A$, seven men (16\%) in group $B$, and one man $(6 \%)$ in group $C$ had values within the normal range. The mean levels for all groups are significantly higher than the normal mean $(P<0.01)$ and $A$ and $B$ and $A$ and $C$ differ significantly $(P<0.05)$, but $B$ and $C$ do not $(P=0 \cdot 2)$. With this estimation there is a considerably greater overlap in the three groups than with either the urinary coproporphyrin or the urinary ALA estimations (Fig. 2) but $30 \%$ of group A, $60 \%$ of group B, and all but four $(78 \%)$ in group $C$ have levels greater than $60 \mu \mathrm{g}$. lead/100 g. blood, similar to the numbers in each group with urinary ALA levels greater than $2 \mathrm{mg}$./100 mg.
A
B
C

URINE PBG in

$\mathrm{mg} / 100 \mathrm{mg}$ Creatinine

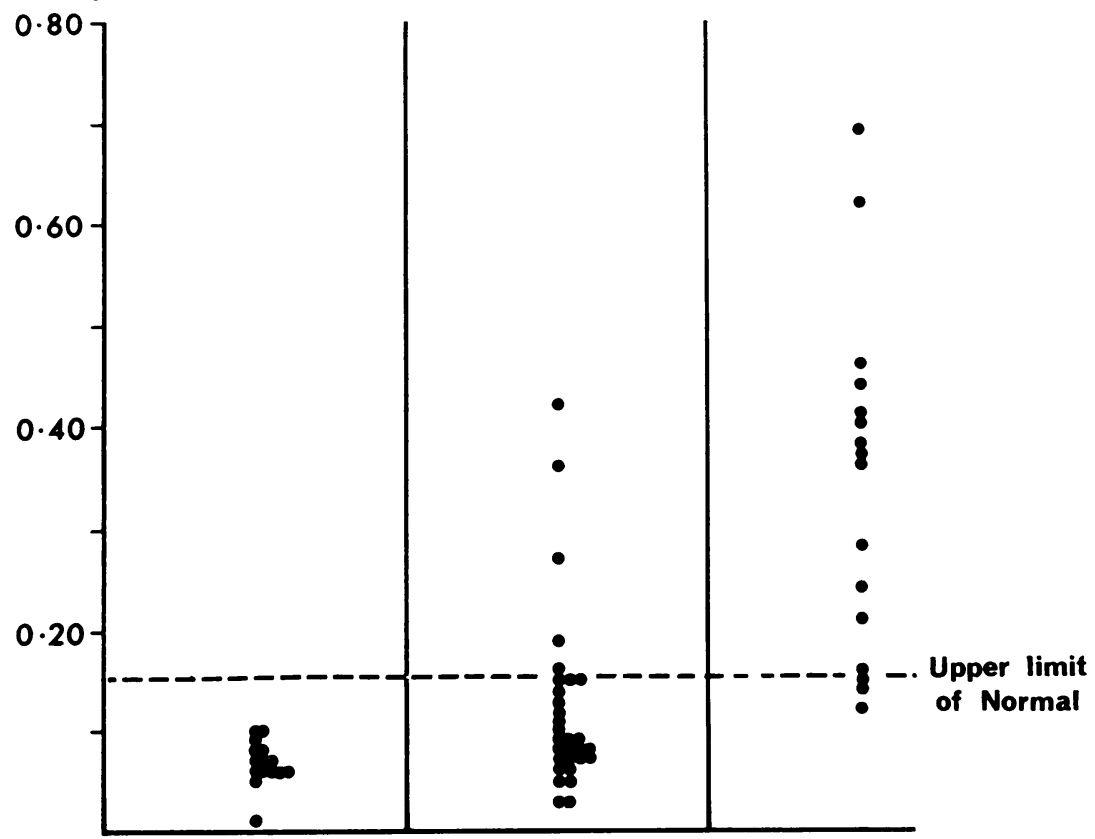

Fig. 3. Comparison of the values for urinary porphobilinogen (PBG) for the three groups $A, B$, and $\mathrm{C}$. 
creatinine (Table IV). This figure of $60 \mu \mathrm{g}$. lead/100 g. blood is therefore proposed as the upper acceptable limit for this estimation although in the whole series no significant correlation was found between blood lead and either urinary coproporphyrin $(r=0 \cdot 16)$ or urinary ALA $(r=0 \cdot 16)$.

Blood Pressure, Blood Urea, Serum Uric Acid, Age, and Duration of Exposure Blood pressure, blood urea, and serum uric acid were estimated in all individuals in an attempt to elucidate whether or not lead exposure predisposes to hypertension and renal damage. The mean diastolic blood pressures of groups $A, B$, and $C$ were 82,82 , and $74 \mathrm{~mm}$. of mercury respectively. The mean ages of the groups were 37,39 , and 37 years respectively, and the mean durations of exposure 7,8 , and 9 years respectively (Table II).

The serum uric acid values were likewise similar for each group, the mean values being $4 \cdot 7,4 \cdot 8$, and $4.7 \mathrm{mg}$. $/$ I00 $\mathrm{ml}$. serum for $\mathrm{A}, \mathrm{B}$, and $\mathrm{C}$ respectively (Table II).

The mean values for blood urea were $34 \cdot 4,38 \cdot 2$, and $42.3 \mathrm{mg}$. $/ 100 \mathrm{ml}$. blood for $\mathrm{A}, \mathrm{B}$, and $\mathrm{C}$ respectively (Table II), and although the means of $A$ and $B$ and $B$ and $C$ are not significantly different, the means of $A$ and $C$ are significantly different $(P<0.01)$. Five men in group $A$, six in group $B$, and six in group $C$ showed trace amounts of proteinuria as tested by the 'albustix test'. Addis counts, a count of the white cells in a centrifuged ro-ml. sample of urine, performed by the method of McGeachie and Kennedy (1963), on 15 men from group A, I5 from group B, and io from group C showed no abnormality. These included all men with proteinuria.

\section{Discussion}

Any worker exposed to lead dust or fume will absorb some lead and will have a raised blood lead level and will therefore excrete lead in the urine (Kehoe, Thamann, and Cholak 1933; Kehoe, Cholak, Hubbard, Bambach, and McNary, 1943).
Not all men, however, with evidence of lead exposure are in danger of developing symptoms of lead toxicity (Kehoe, 1964; Lane, 1964). The difficulty is to recognize when a 'state of exposure' merges into a 'state of toxicity'. Even when some of the symptoms and signs of lead poisoning appear, difficulties may still be encountered as few are specific for lead poisoning.

Much has been published on the tests considered to be most helpful in assessing the state of the lead worker with respect to lead. Apart from a brief history and clinical examination the tests most commonly used by factory doctors are serial haemoglobins, stippled cell counts, and a semiquantitative urinary coproporphyrin estimation (Cramér and Dahlberg, 1966). These tests are easily and rapidly performed and are thus applicable to the frequent checking of large numbers of workmen. King and Thompson (I96I) and Johnstone (1964), however, regard basophilic stippling as being unreliable, and Lane (1964) advocates the use of blood and urine lead estimations and considers that the urinary coproporphyrin test is too sensitive.

Clinical Significance of Laboratory Tests Urinary coproporphyrin (de Langen and ten Berg, I948; Waldman and Seideman, I950; Maloof, I950; Brooks, I95I; Malcolm, 1965) and urinary ALA (Haeger, 1957; Cramér and Selander, 1965) have been considered useful in the detection of lead exposure but in all these papers no real difference has been drawn between exposure and intoxication.

The presence of anaemia and of raised levels of urinary coproporphyrin, ALA, and PBG reflect significant effects on haem and haemoglobin metabolism and hence are more likely to reflect the degree of lead toxicity than blood and urine lead levels which merely indicate the degree of lead absorption (Schrenk, 1959). Individuals, moreover, vary in their sensitivity to toxic agents. It is, therefore, not surprising that no correlation was found between tests which measure exposure to lead (urinary and blood lead) and those which measure interference with tissue enzymes caused by

TABLE II

Mean Values for Age, Length of Time Worked, Diastolic Blood Pressure, Blood Urea, and Serum URIC ACID FOR THE Three Groups

\begin{tabular}{c|c|c|c|c|c}
\hline Group & $\begin{array}{c}\text { Diastolic B.P. } \\
(\mathrm{mm} . \mathrm{Hg})\end{array}$ & $\begin{array}{c}\text { Age } \\
(\mathrm{yrs})\end{array}$ & $\begin{array}{c}\text { Blood Urea } \\
(\mathrm{mg} . / \mathrm{I00} \mathrm{ml.})\end{array}$ & $\begin{array}{c}\text { Serum Uric Acid } \\
(\mathrm{mg} / \mathrm{I} 00 \mathrm{ml} .)\end{array}$ & $\begin{array}{c}\text { Time Worked } \\
(y r s)\end{array}$ \\
\hline A & $\mathbf{8 2}$ & 37 & $34 \cdot 4$ & $4 \cdot 7$ & 7 \\
B & $\mathbf{8 2}$ & 39 & $38 \cdot 2$ & $4 \cdot 8$ & 8 \\
C & 74 & 37 & $42 \cdot 3$ & $4 \cdot 7$ & 9 \\
\hline
\end{tabular}


TABLE III

Correlations Found by Previous Authors compared with Those Found in the Present Study

\begin{tabular}{|c|c|c|}
\hline Correlation & Author & \\
\hline Positive correlation between urinary coproporphyrin and urinary lead excretion & $\begin{array}{l}\text { Waldman and Seideman } \\
\text { Maloof } \\
\text { Haeger-Aronsen } \\
\text { Cramér and Selander }\end{array}$ & $\begin{array}{l}(1950) \\
(1950) \\
(1960) \\
(1965)\end{array}$ \\
\hline Positive correlation between urinary ALA and urinary lead excretion & $\begin{array}{l}\text { Haeger-Aronsen } \\
\text { Cramér and Selander }\end{array}$ & $\begin{array}{l}(1960) \\
(1965)\end{array}$ \\
\hline $\begin{array}{l}\text { Positive correlation between urinary coproporphyrin and blood lead } \\
\text { No correlation between semi-quantitative urinary coproporphyrin and blood } \\
\text { lead }\end{array}$ & $\begin{array}{l}\text { Brooks } \\
\text { Meek, Mooney and Harrold }\end{array}$ & $\begin{array}{l}(1951) \\
(1948)\end{array}$ \\
\hline $\begin{array}{l}\text { No correlation between urinary coproporphyrin and ALA excretion } \\
\text { Positive correlation between urinary ALA and PBG and clinical manifestations }\end{array}$ & $\begin{array}{l}\text { de Kretser and Waldron } \\
\text { Cramér and Selander }\end{array}$ & $\begin{array}{l}(1963) \\
(1965)\end{array}$ \\
\hline $\begin{array}{l}\text { Positive correlation between urinary coproporphyrin and ALA excretion } \\
(r=0.79) \\
\text { Positive correlation between urinary coproporphyrin and haemoglobin level } \\
(r=0.54) \\
\text { Positive correlation between urinary ALA and haemoglobin level }(r=0.57) \\
\text { Positive correlation between urinary coproporphyrin and ALA and clinical } \\
\text { assessment } \\
\text { Positive correlation between rise in urinary PBG and presence of symptoms } \\
(P<0.01) \\
\text { No correlation between urinary coproporphyrin or ALA and blood lead } \\
(r=0.16) \\
\text { No correlation between urinary coproporphyrin or ALA and urinary lead } \\
(r=0.17)\end{array}$ & Observations from present study & \\
\hline
\end{tabular}

lead (haemoglobin level, and urinary coproporphyrin, ALA, and PBG levels). Furthermore, the tests indicative of this interference correlate more closely with the clinical assessment than do those which reflect exposure. The haemoglobin level could not be correlated directly with the clinical grouping as it formed a part of it, but the haemoglobin level correlates significantly with the urinary coproporphyrin $(r=0.54)$ and ALA $(r=0.57)$ $(\mathbf{P}<0.05$ in both cases). This agrees with the findings of Chisolm and Harrison (1956) and of Haeger-Aronsen (1960) that the urinary excretion of coproporphyrin and of ALA respectively are sensitive indices of 'metabolically active' and presumably toxic lead in the body.

The results of the present study confirm that the urinary coproporphyrin level is a very sensitive test of exposure to lead (Lane, 1964) and also indicate that it is of value in the total appraisal of the individual's reaction to lead. Studies in experimental lead poisoning in rabbits (Gibson and Goldberg, unpublished data) show that the urinary coproporphyrin rises immediately on exposure to lead and that the urinary ALA shows a rise after about one to two weeks of continual dosage. Urinary PBG begins to rise above normal levels only after several weeks of continual dosage. This animal work confirms the results of the present study in lead workers that the urinary coproporphyrin and ALA become abnormal on exposure to lead, whereas a rise in the urinary $P B G$ is a much later sign occurring only with the onset of symptoms. This finding is of particular significance because of the close similarity between the clinical manifestations of lead poisoning and acute intermittent porphyria (Dagg, Goldberg, Lochhead, and Smith, 1965) in which there is often a marked rise in urinary PBG as well as ALA with the onset of acute symptoms.

Evidence of Toxicity The majority of men in group $\mathbf{A}$ have urinary coproporphyrin values below $80 \mu \mathrm{g} . / 100 \mathrm{mg}$. creatinine (equivalent approximately to $800 \mu \mathrm{g}$./litre urine) whereas all but one man in group C and $75 \%$ of group B have values above this level (Fig. 2.) The majority of the men in group A have urinary ALA values below $2.0 \mathrm{mg}$. ALA/100 mg. creatinine $(2.0 \mathrm{mg}$. $/ 100 \mathrm{ml}$. urine), while all but three men in group $C$ and $60 \%$ of group B have values above this level (Fig. 2). Furthermore, the value of $80 \mu \mathrm{g}$. urinary coproporphyrin/100 mg. creatinine corresponds to that of $2.0 \mathrm{mg}$. urinary $\mathrm{ALA} / \mathrm{r} 00 \mathrm{mg}$. creatinine when 
ALA

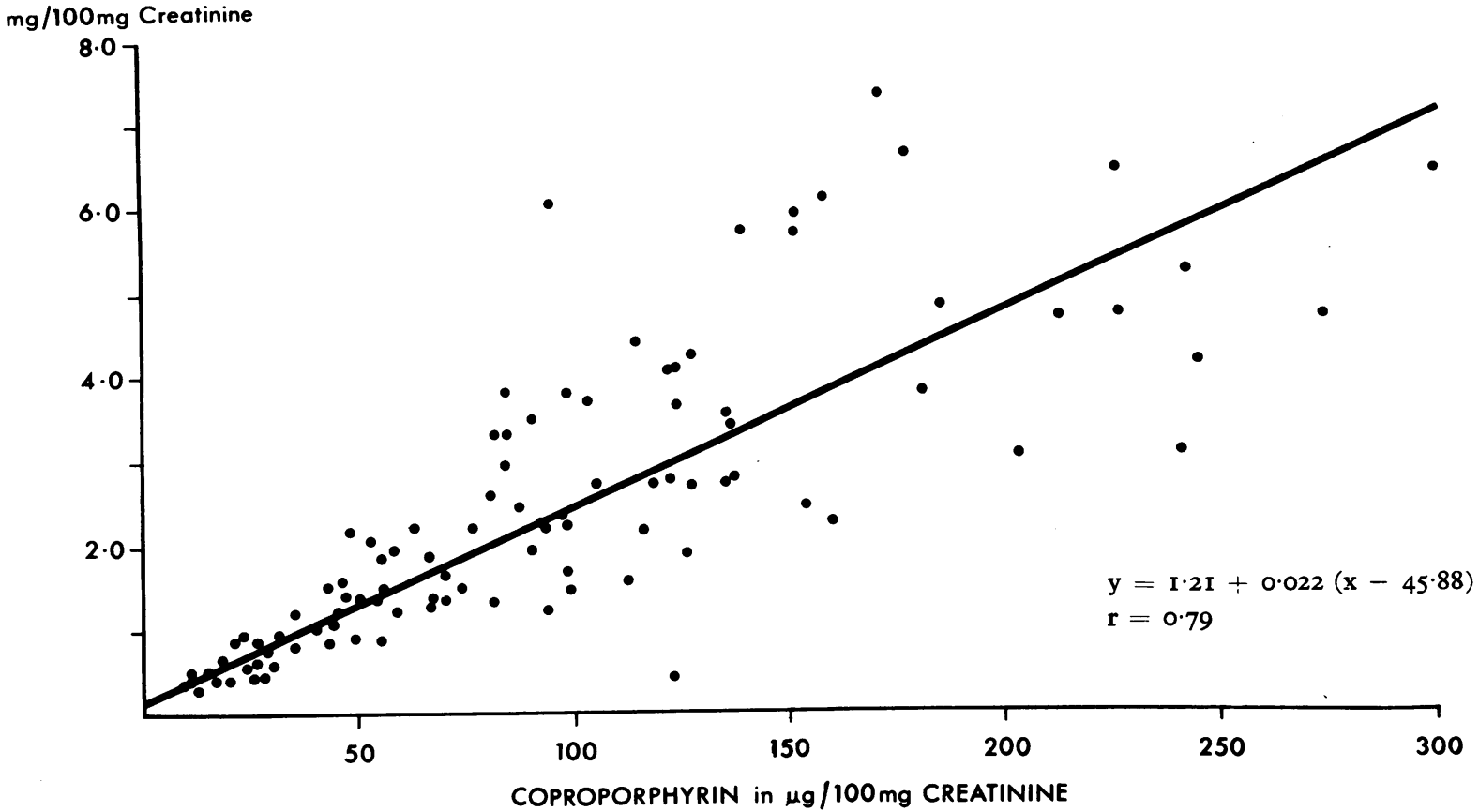

FIG. 4. Graph of urinary ALA against urinary coproporphyrin for the whole series of 100 men.

correlating these estimations (Fig. 4). It is therefore considered that these values should be taken as indicative of dangerous lead absorption. The numbers of men above and below the critical limits in groups $\mathrm{A}, \mathrm{B}$, and $\mathrm{C}$ are presented in Table IV and compared with the number with blood lead levels greater and less than $60 \mu \mathrm{g}$. lead/100 g. blood. The value for coproporphyrin agrees with that proposed by Lane (1964) of $800 \mu \mathrm{g}$./litre. Any man with a urinary PBG value of $0.15 \mathrm{mg} . / 100 \mathrm{mg}$. creatinine or over should be considered in imminent danger of developing symptoms of lead poisoning if these are not already present. As the urinary coproporphyrin level is such a sensitive test, any man with a normal level is unlikely to have suffered recent exposure to lead. A raised urinary PBG level is also of value where doubt arises as to whether the symptoms of colic and constipation are in fact due to lead poisoning. The level never rises to that found in the acute stages of acute intermittent porphyria.

Table V summarizes the evidence of toxicity

TABLE IV

Comparison of THE Numbers of MEN IN GRoups A, B, AND C WITH URINARY Coproporphyrin, URINARY $\delta$-aminolaevulinic Acid, and Blood Lead Greater and Less Than the Critical Levels

\begin{tabular}{|c|c|c|c|c|c|c|}
\hline \multirow[b]{2}{*}{ Group } & \multicolumn{2}{|c|}{$A(37$ men $)$} & \multicolumn{2}{|c|}{$B(45$ men $)$} & \multicolumn{2}{|c|}{$C(\mathrm{I} 8 \mathrm{men})$} \\
\hline & $\begin{array}{c}\text { Above Critical } \\
\text { Level }\end{array}$ & $\begin{array}{c}\text { Below Critical } \\
\text { Level }\end{array}$ & $\begin{array}{c}\text { Above Critical } \\
\text { Level }\end{array}$ & $\begin{array}{c}\text { Below Critical } \\
\text { Level }\end{array}$ & $\begin{array}{c}\text { Above Critical } \\
\text { Level }\end{array}$ & $\begin{array}{c}\text { Below Critical } \\
\text { Level }\end{array}$ \\
\hline $\begin{array}{l}\text { Urinary coproporphyrin } \\
\text { Urinary ALA }^{2} \\
\text { Blood lead }^{3}\end{array}$ & $\begin{array}{l}5 \\
8 \\
\text { II }\end{array}$ & $\begin{array}{l}32 \\
29 \\
26\end{array}$ & $\begin{array}{l}33 \\
28 \\
27\end{array}$ & $\begin{array}{l}12 \\
17 \\
18\end{array}$ & $\begin{array}{l}17 \\
15 \\
14\end{array}$ & $\begin{array}{l}1 \\
3 \\
4\end{array}$ \\
\hline
\end{tabular}

1 Critical level $80 \mu \mathrm{g}$./100 mg. creatinine

2 Critical level $2.0 \mathrm{mg}$./100 mg. creatinine

${ }^{3}$ Critical level $60 \mu \mathrm{g}$./100 g. blood 
TABLE V

Evidence of Toxicity

\begin{tabular}{|c|c|c|c|c|}
\hline \multicolumn{3}{|c|}{ Series } & Safe Range & Danger Levels \\
\hline Lane (1964) . . & . & $\cdots$ & $\begin{array}{l}\text { Blood lead less than } 80 \mu \mathrm{g} . / 100 \mathrm{ml} \text {. blood } \\
\text { Urinary lead less than } 150 \mu \mathrm{g} . / \text { litre } \\
\text { Haemoglobin over } 13 \mathrm{~g} . \%(90 \%) \\
\text { Punctate basophilia less than } 10,000 / 10^{6} \\
\text { red cells } \\
\text { Urinary coproporphyrin }+++(500 \mu \mathrm{g} . / \\
\text { litre) or less }\end{array}$ & $\begin{array}{l}\text { Blood lead over } 80 \mu \mathrm{g} . / 100 \mathrm{ml} \text {. blood } \\
\text { Urinary lead over } 200 \mu \mathrm{g} . / \text { litre } \\
\text { Haemoglobin less than } 13 \mathrm{~g} . \% \text { or falling } \\
\text { haemoglobin } \\
\text { Punctate basophilia of } 5-20,000 / 10^{6} \mathrm{red} \\
\quad \text { cells } \\
\text { Urinary coproporphyrin }++++(800 \mu \mathrm{g} . / \\
\text { litre) }\end{array}$ \\
\hline Present study & & $\ldots$ & $\begin{array}{l}\text { Haemoglobin over I3 g. } \%(90 \%) \\
\text { Urinary coproporphyrin less than } 80 \mu \mathrm{g} . / \\
\text { I00 mg. creatinine }(800 \mu \mathrm{g} . / \text { litre }) \\
\text { Urinary ALA less than } 2.0 \mathrm{mg} \cdot / 100 \mathrm{mg} \text {. } \\
\text { creatinine }(2 \cdot 0 \mathrm{mg} . \%) \\
\text { Blood lead less than } 60 \mu \mathrm{g} . / \mathrm{I} 00 \mathrm{~g} . \text { blood. }\end{array}$ & $\begin{array}{l}\text { Haemoglobin less than } 13 \mathrm{~g} . \% \text { or falling } \\
\text { haemoglobin } \\
\text { Urinary coproporphyrin over } 80 \mu \mathrm{g} . / 100 \mathrm{mg} \text {. } \\
\text { creatinine }(800 \mu \mathrm{g} . / \text { litre) } \\
\text { Urinary ALA over } 2.0 \mathrm{mg} . / 100 \mathrm{mg} \text {. creati- } \\
\text { nine }(2.0 \mathrm{mg} . \%) \\
\text { Blood lead over } 60 \mu \mathrm{g} . / 100 \mathrm{~g} . \text { blood } \\
\text { Urinary PBG over } 0.15 \mathrm{mg} . / 100 \mathrm{mg} \text {. } \\
\text { creatinine }(0.15 \mathrm{mg} . \%)\end{array}$ \\
\hline
\end{tabular}

found in this series and compares it with that proposed by Lane (1964). The value of $60 \mu \mathrm{g}$. lead/100 g. blood is included in this table although this estimation is evidence of exposure and not strictly of toxicity.

Renal Damage Due to to Lead Poisoning Lane (1964) has stressed the importance of recognizing a state of latent lead toxicity in which workers have absorbed toxic quantities of lead and, although apparently well, may develop renal damage. While there seems to be little doubt that renal damage can follow lead poisoning in children (Henderson, 1955; Henderson and Inglis, 1957) and lead poisoning in adults resulting from oral ingestion of lead over long periods (Morgan, Hartley, and Miller, 1966; Danilović, 1958), a marked relationship is not generally accepted in industrial lead exposure (Aub, Fairhall, Minot, and Reznikoff, 1926; Kehoe, 1964; Johnstone, I964).

No conclusive evidence was obtained on this point from this survey. The raised blood urea level of group $C$ cannot be explained either by age or by hypertensive renal damage. It was at first considered to be due to a transient drop in the glomerular filtration rate (GFR) as a result of abdominal colic and vomiting, causing a pre-renal azotaemia, but the GFR, as measured by the creatinine clearance test, was normal in nine patients in whom this was carried out within three to five days of admission. This also indicates that it was unlikely to have been due to transient intrinsic renal damage. The presence of proteinuria bore no relation to the degree of exposure or intoxication. A fuller su rvey of the effects of lead on the kidney will be the subject of a future publication.

Relative Hazard of Different Industries Seven industrial firms co-operated in this survey providing 98 of the 100 men studied. Some firms had new factories with modern engineering precautions to reduce the lead hazard, e.g., the car-body manufacturing plant, while others, e.g., the wiremanufacturing plant and the lead refinery, were old. Others, e.g., ship-breaking and scrap-metal burning, presented a hazard less easy to control than in car or battery manufacture. It was, therefore, felt that it would be of interest to compare the average values of haemoglobin, blood lead, urinary lead, coproporphyrin, and ALA obtained for the different firms. These were accordingly tabulated along with the length of service (Table VI).

The workers in four of the firms, battery manufacture, scrap-metal burning, and the two shipbreaking firms, show mean urinary coproporphyrin values greater than $80 \mu \mathrm{g}$./100 mg. creatinine, urinary ALA values greater than $2 \cdot 0 \mathrm{mg} . / 100 \mathrm{mg}$. creatinine, and blood lead values in excess of 60 $\mu \mathrm{g}$. $/ 100 \mathrm{~g}$. blood, while in three of the firms the mean haemoglobin values are less than $13 \mathrm{~g} . / 100 \mathrm{ml}$.

The workers in the car-body plant and lead refinery have mean haemoglobin values just over and mean urinary coproporphyrin and ALA values just under the critical levels, while the mean blood lead value for those in the new car-body plant is greater than $60 \mu \mathrm{g}$. $/ 100 \mathrm{~g}$. blood and that for those in the old lead refinery is less than $60 \mu \mathrm{g}$. $/ 100 \mathrm{~g}$. 
TABLE VI

Average Values for Hb, Urinary Lead, Urinary Coproporphyrin, Urinary ALA, Blood Lead, and LeNGTH of SERVICE FOR THE SEVEN FIRMS

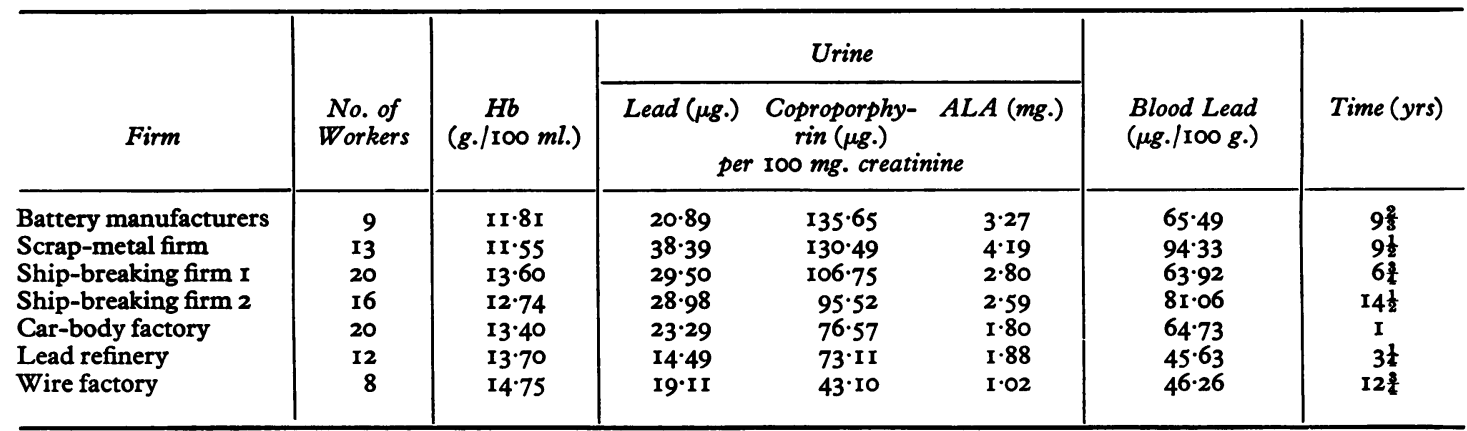

blood. The least hazard in this series was encountered in the wire-manufacturing factory, where $50 \%$ of the workers were excluded from the survey as they had no evidence of exposure to lead.

It was not surprising to find that industries such as scrap metal burning and ship-breaking should show a generally dangerous level of exposure to lead, since lead fume, often produced in confined spaces, is difficult to control and the wearing of masks difficult to enforce when continual supervision of the men at work is not feasible. In the wire-manufacturing factory, on the other hand, lead was used only as a molten bath and the exposure hazard was less severe.

Workmen in the lead refinery and the car-body plant had similar mean values. The lead refinery was an old factory whereas the car plant was new, having been in operation for just under two years, with the mean length of service one year. It was equipped with modern devices for the removal of lead dust, the lead hazard in this industry, and the high level of exposure was probably largely due to the workmen removing the excess lead solder while not in the specially installed 'discing booths'.

In conclusion it may be said that in some lead industries by their very nature, e.g., scrap-metal burning and ship-breaking, and in others despite modern technical control, a considerable lead hazard still exists. From the results of this survey it is felt that routine haemoglobin and urinary coproporphyrin, ALA, and PBG estimations are of most value in screening the men at risk. A steadily falling haemoglobin or a haemoglobin below $13 \mathrm{~g}$./100 ml., if other causes for this are excluded, is a warning sign, while the upper safety limits for urinary coproporphyrin and urinary ALA are $80 \mu \mathrm{g} . / 100 \mathrm{mg}$. creatinine $(800 \mu \mathrm{g}$./litre) and $2.0 \mathrm{mg}$./100 mg. creatinine ( $2.0 \mathrm{mg} . \%)$ respectively.
Ideally, values of this order should never be encountered. A rise in urinary PBG above 0.15 $\mathrm{mg}$./100 mg. creatinine indicates acute lead poisoning. The blood lead estimation does not differentiate between lead exposure and lead toxicity but values above $60 \mu \mathrm{g}$. lead/100 g. blood should alert the physician to carry out other tests.

We wish to acknowledge the help and co-operation of Dr. A. T. Doig, H.M. Deputy Senior Inspector of Factories, and of the managements and medical officers of the firms involved in this study; the co-operation of Dr. E. B. Hendry, of the Biochemistry Department of the Western Infirmary, for blood urea and serum uric acid estimations; and the able technical assistance of $\mathrm{Mr}$. John A. McConnellogue. This work was aided by a grant from the Nuffield Foundation.

\section{REFERENCES}

Aub, J. C., Fairhall, L. T., Minot, A. S., and Reznikoff, P. (I926). Lead Poisoning (Medical monographs, vol 7.) Williams and Wilkins, Baltimore. Reprinted from Medicine (Baltimore) 4, I-250 (1925).

Brooks, A. L. (I95I). An appraisal of a urinary porphyrin test in detection of lead absorption. Industr. Med. Surg., 20, 390-392.

Brunton, G. (1937). Mostagedda and the Tasian Culture [British Museum Expedition to Middle Egypt, 1928, 1929]. Bernard Quaritch, London.

Byers, R. K. (1959). Review article. Lead poisoning. Review of the literature and report on 45 cases. Pediatrics, 23, 585-603.

Caraway, W. T. (1955). Determination of uric acid in serum by a carbonate method. Amer. F. clin. Path., 25, 840-845

Chisolm, J. J. jun., and Harrison, H. E. (1956). Quantitative urinary coproporphyrin excretion and its relation to edathamil calcium disodium administration in children with acute lead intoxication. $\mathcal{F}$. clin. Invest., 35, $1131-1138$.

Cramér, K., and Dahlberg, L. (1966). Incidence of hypertension among lead workers. Brit. f. industr. Med., 23, IOI-IO4. 
Cramér, K., and Selander, S. (1965). Studies in lead poisoning. Comparison between different laboratory tests. Ibid., 22, 31 I-314.

Dagg, J. H., Goldberg, A., Lochhead, A., and Smith, J. A. (1965). The relationship of lead poisoning to acute intermittent porphyria. Quart. F. Med. (N.S.), 34, I63-I75.

Danilović, V. (1958). Chronic nephritis due to ingestion of lead-contaminated flour. Brit. med. F., 1, 27-28.

de Kretser, A. J., and Waldron, H. A. (1963). Urinary delta amino-laevulinic acid and porphobilinogen in leadexposed workers. Brit. F . industr. Med., 20, 35-40.

de Langen, C. D., and ten Berg, J. A. G. (1948). Porphyrin in the urine as a first symptom of lead poisoning. Acta med. scand., 130, 37-44.

Goldberg, A., Smith, J. A., and Lochhead, A. C. (1963). Treatment of lead poisoning with oral penicillamine. Brit.med.F , I, 1270-1275.

Gonzales, T. A., Vance, M., and Helpern, M. (1954). Legal Medicine; Pathology and Toxicology, 2nd ed. AppletonCentury-Crofts, New York.

Haeger, B. (1957). Increased content of a delta-aminolaevulic acid-like substance in urine from workers in lead industry. Scand. F. clin. Lab. Invest., 9, $211-212$.

Haeger-Aronsen, B. (1960). Studies on urinary excretion of delta-aminolaevulic acid and other haem precursors in lead workers and lead-intoxicated rabbits. Ibid., 12, Suppl. 47.

Hawk, P. B., Oser, B. L., and Summerson, W. H. (1953). Practical Physiological Chemistry, 12th ed. Blakiston, Philadelphia.

Henderson, D. A. (1955). Chronic nephritis in Queensland. Aust Ann. Med., 4, 163-177.

- , and Inglis, J. A. (1957). The lead content of bone in chronic Bright's disease. Ibid., 6, I45-154.

Hunter, D. (1962). The Diseases of Occupations, 3rd ed. The English Universities Press, London.

Johnstone, R. T. (1964). Clinical inorganic lead intoxication. Arch. environm. Hlth, 8, 250-255.

- (r966). Occupational disease. f. occup. Med., 8, 214-2 r9.

Kehoe, R. A. (1964). Metabolism of lead under abnormal conditions. Arch. environm. Hlth, 8, 235-243.
-, Cholak, J., Hubbard, D. M., Bambach, K., and McNary, R. R. (I943). Experimental studies on lead absorption and excretion and their relation to the diagnosis and treatment of lead poisoning. $\mathcal{F}$. industr. Hyg., 25, 7I-79.

-, Thamann, F., and Cholak, J. (1933). Lead absorption and excretion in relation to the diagnosis of lead poisoning. Ibid., 15, 320-340.

$\longrightarrow,-$ and - (1935). Normal absorption and excretion of lead. F. Amer. med. Ass., 104, 90-92.

King, E., and Thompson, A. R. (196r). The measurement of lead absorption in industry. Ann. occup. Hyg., 3, 247263.

Lane, R. E. (1964). Health control in inorganic lead industries. Arch. environm. Hlth, 8, 243-250.

McGeachie, J., and Kennedy, A. C. (1963). Simplified quantitative methods for bacteriuria and pyuria. F. clin. Path., 16, 32-38.

Malcolm, D. (1965). Industrial control of personnel. Ann. occup. Hyg., 8, 35-42.

Maloof, C. C. (1950). Role of porphyrins in occupational diseases. Arch. industr. Hyg., 1, 296-307.

Mauzerall, D., and Granick, S. (1956). The occurrence and determination of delta-aminolevulinic acid and porphobilinogen in urine. F. biol. Chem., 219, 435-446.

Meek, S. F., Mooney, T., and Harrold, G. C. (1948). Urinary porphyrins in lead poisoning. Industr. Med. Surg., 17, 469-47I.

Ministry of Labour (1965) Annual Report of H.M. Chief Inspector of Factories on Industrial Health, 1964. H.M.S.O., London.

Morgan, J. M., Hartley, M. W., and Miller, R. E. (1966). Nephropathy in chronic lead poisoning. Arch. intern. Med., I18, 1 7-29.

Rimington, C. (196I). Quantitative determination of porphobilinogen and porphyrins in urine and faeces. Ass. clin. Path. Broadsheet No. 36. (New Series).

Schrenk, H. H. (1959). Hygienic lead standards. Industr. Med. Surg., 28, 106-109.

Skeggs, L. T. (1957). An automatic method for colorimetric analysis. Amer. F. clin. Path., 28, 31 I-322.

Waldman, R. K., and Seideman, R. M. (I950). Reliability of the urinary porphyrin test for lead poisoning. Arch. industr. Hyg., 1, 290-295. 
-how to start and when to stop-and explains the special psychological atmosphere of general practice.

Section 3 presents conclusions. The result of five years' research is a number of problems, awkward and uncomfortable. Advice by the doctor is usually a well intended shot in the dark, nearly always futile, as is reassurance.

General practice is seriously ill with a benign disease and if the right therapy is applied the prognosis is good. The present symptoms of malaise in general practice are of the doctors' own making, and Dr. Balint believes that he has presented the symptoms and diagnosis of this malady and urges doctors to try to effect a radical cure.

An appendix gives hints to psychiatrists who are taking general practitioners in refresher courses on the selection of general practitioners for these courses and follow up details of the patients discussed in the seminars at the Tavistock Clinic.

It is disappointing that the book raises more problems than it answers and gives little advice. It certainly does not give short cuts or simple rules to lessen the burden of the 'neurotic' patient in general practice.

Not everyone will accept Balint's teaching, and it will cause antagonism among many. Some will still believe in shutting the door firmly on the neurotic skeleton in the cupboard as being the most economical way of dealing with this problem.

The book should be compulsory reading for all students, specialists, and general practitioners.

H. W. ASHWORTH

\section{NOTICES}

\section{Asian Conference on Occupational Health}

The Vth Asian Conference on Occupational Health will be held in Bombay (India) in November 1968. The Conference will be attended by experts on various aspects of occupational health from many parts of the world.

Scientific discussions will be held on various subjects pertaining to occupational health, such as Safety in Industry, Industrial Hygiene, and Ergonomics.

For further information please write to Dr. J. C. Kothari, Secretary-General, P.B. No. 355, Bombay, India.

\section{The British Occupational Hygiene Society}

A Third International Symposium on Inhaled Particles is to be held in September 1970 in the United Kingdom (provisionally at the Imperial College of Science and Technology, London). It is a sequel to the earlier symposia held at Oxford in 1960 and at Cambridge in 1965 .
This conference, whilst maintaining the previous general theme of the advances in knowledge of the mechanisms governing the entry of foreign material into the lungs and the response of the lungs to inhaled matter, will concentrate on the application of this basic knowledge to the particular problems of coal-workers' and industrial mixed dust pneumoconiosis.

Contributions to the Symposium will be welcome from all countries. They should in general describe original research but some review papers will be accepted. Contributions will be subject to scrutiny by the Society's Honorary Editor with the assistance of an advisory panel.

The Symposium is expected to last $4 / 5$ days; simultaneous translation will be provided in English, French, and German (and other languages, depending on requirements). The proceedings will subsequently be published in book form, full details of which will be announced later.

Persons wishing to receive further details and/or to present contributions should write to the Secretary of the Organizing Committee: Dr. J. S. McLintock, Medical Service, National Coal Board, Hobart House, Grosvenor Place, London, S.W.r.

\section{Second Scottish Symposium on Colour}

Organized by the Colour Group (Scottish Section) and the Visual Laboratory of the Department of Psychology, Edinburgh University, the Symposium will be held in the David Hume Tower, Edinburgh University, George Square, Edinburgh, on Thursday and Friday, 5 and 6 September, 1968. Further information may be obtained from the Hon. Secretary, R. S. Sinclair, Paisley College of Technology, Paisley, Scotland.

\section{CORRECTIONS}

In the paper 'The Diagnosis of Industrial Lead Poisoning' by Gibson, Mackenzie, and Goldberg (Brit. F. industr. Med., 1968, 25, 40-5I) reference was made in Table III on p. 47 to the findings of Cramér and Selander on the correlation between urinary ALA and PBG and clinical manifestations. This was incorrect, for in the paper by Cramér and Selander which was quoted there were no data on the urinary excretion of PBG.

In the paper 'Assessing the Heat Stress and Establishing the Limits for Work in a Hot Mine' by Wyndham, Allan, Bredell, and Andrew (Brit. F. Industr. Med., 1967, 24, 255-27I), line 3 on p. 264 should read "This statement means that the same effect on $P_{4} S R$ values is seen from a $10^{\circ} \mathrm{F}$. change in D.B. and a $30^{\circ} \mathrm{F}$. change in G.T." 